\title{
TOURISM DEVELOPMENT OF OHRID (NORTH MACEDONIA)
}

\author{
DOI: http://dx.doi.org/10.18509/GBP.2020.67 \\ UDC: 338.48.055.2:711.4]:303.022/.023(497.771)"2011/2017"
}

\author{
Biljana Petrevska ${ }^{1}$ \\ Noga Collins-Kreiner ${ }^{2}$ \\ ${ }^{1}$ Faculty of Tourism and Business Logistics, Goce Delčev University - Štip, North Macedonia \\ ${ }^{2}$ Department of Geography and Environmental Studies, University of Haifa, Israel
}

\begin{abstract}
The study investigates the current level of tourism development of Ohrid by applying the Tourism Area Life Cycle (TALC) model. The main aim is to assess how much the city has changed due to tourism expansion. In this line, the research explores each TALC stage by an in-depth analysis of Ohrid's urban transformation. By employing qualitative and quantitative data, the study deeply elaborates many secondary sources along with the TALC model. The results point that some parts of Ohrid (like the old town) is experiencing negative reshaping as a result of tourism, thus provoking unsustainable quantitative growth in a spatially limited, non-expandable, and particularly fragile segment. The general findings indicate that over the years, tourism in Ohrid has exceeded its carrying capacity, beginning to cause damage to the social, cultural, and environmental fabric of the city. Hence, the study recommends that local tourism decision-makers must shift the focus of tourism policy towards qualitative growth, or Ohrid will either lose its environmental balance or its authenticity and livability, and most likely both.
\end{abstract}

Keywords: TALC model; Urban transformation; Tourism expansion; Tourism policy.

\section{INTRODUCTION}

Ohrid is the best known tourist destination in North Macedonia, and accounts for onethird of all tourist arrivals and overnights recorded in the country. As a historical city first mentioned in 353 B.C., and being one of the oldest human settlements in Europe, Ohrid attracts a large number of tourists that often reaches the potential critical point [37] for the region's physical and social carrying capacities [1], [6], [33], [39], [41].

Due to rapid tourism expansion, Ohrid has experienced an urban reshaping. The article explores the manner in which Ohrid has been profoundly transformed by tourism development in terms of landscape, economic dynamics, and functional dimensions. The paper is structured into several sections. It begins with a brief overview on literature referring urban tourism and city's transformation, followed by some stylized facts as background material on the case study. This is followed by a presentation of the research methodology. The main focus is on findings addressing the tourism development of Ohrid according to its tourism life cycle.

\section{LITERATURE REVIEW}

The issue of urban tourism is vastly explored [3], [8], [12], [15], [16], [20], [23], [36]. As of 1980s the demand for urban tourist destinations began to increase rapidly, thus making the cities interesting tourist destinations [10], [17].

Today, urban tourism makes a significant contribution to the economic basis of cities and has an impact on both, local human activity and city shape [35]. So, tourist activity in the 
city becomes important component of its economic basis [9], [13]. Furthermore, many facilities and functions (such as museums, galleries, theatres, and sports and business facilities) are designated for residents, although their large scale also makes them attractive to tourists as well [2].

\section{CURRENT TOURISM DEVELOPMENT OF OHRID (NORTH MACEDONIA)}

Ohrid is an ancient city located in the southwest part of North Macedonia, with over 52,000 residents and a long history of tourism. Until 2017, the Southwest planning region was the country's leading statistical region in tourism and regional development [26]. With 365 churches, Ohrid has been referred to as "Jerusalem of the Balkans" [29], [40]. In 1979 and 1980 respectively, Ohrid and Lake Ohrid were designated cultural and natural World Heritage Sites by UNESCO.

Today, the number of tourists and overnights is constantly growing (296,046 visitors and $1,034,858$ overnights in 2018), thus making Ohrid the leading tourism center in the country. It is generally a summer destination, although it has gradually been assuming attributes of a more complex cultural tourism destination. Due to the high number of tourists visiting the area during the third quarter of the year (July-September), Ohrid tourism is characterized by strong and robust seasonality patterns [27].

\section{METHODOLOGY AND RESEARCH FRAME}

The study employs a mixed research method which incorporates qualitative and quantitative data. Besides literature review of many relevant secondary sources (like: official tourism statistical data, historical and contemporary written documents about Ohrid from the Institute of National History and the State Archives of the Republic of North Macedonia), the Tourism Area Life Cycle (TALC) model [5] is applied.

The TALC theory links the level of support of the local people to the degree of development of the destination [38], by elaborating the growing activity through the TALC stages. For this purpose, total annual tourist arrivals to Ohrid constituted the primary unit of measure for tourism development, with a data set covering the period 1956-2017. A detailed assessment of several areas that reflected the city's urban context, with a particularly strong focus on the different conditions relating to the city's economic, political, social and cultural contexts, was performed.

\section{ANALYSIS, FINDINGS AND DISCUSSION}

Figure 1 gives a visual representation of data on the primary variable (total tourist arrivals) for the period 1956-2017 incorporating the following three sub periods:

(1) Sub-Period I (1956-1990), when the Socialist Republic of Macedonia was still an integral part of Yugoslavia and Ohrid was in a socialist phase of development.

(2) Sub-Period II (1991-2001), constitutes a transitional period reflecting both the decline of the first cycle of Sub-Period I and, as the period following the independence of the Republic of Macedonia, the beginning of the second cycle noted in Sub-Period III.

\footnotetext{
${ }^{7}$ During the sample period 1956-2017, North Macedonia had different constitutional names in accordance to changes in the political system. So, between 1956 and 1990 it was named the Socialist Republic of Macedonia, while between 1991 and 2017 its official name was amended to the Republic of Macedonia. Since 2019, in accordance with the Prespa agreement, the name is changed to the Republic of North Macedonia.
} 
(3) Sub-Period III (2002-2017), covers a 15 year period following the independence of the country, including numerous early transitions and democratic challenges.

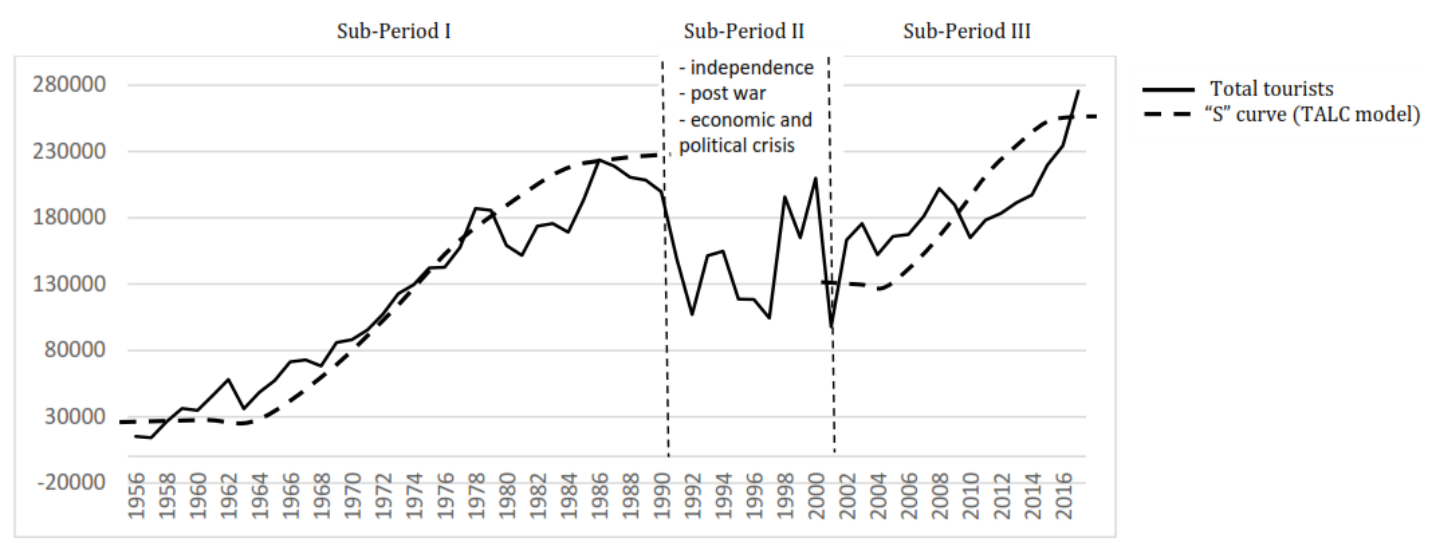

Figure 1. Ohrid's tourism life cycle, 1956-2017 Source: Authors

\section{Sub-Period I (1956-1990)}

During 1956-1990 (Sub-Period I), the life cycle fully conforms to the classic TALC model and consists of almost all its phases, except Stagnation. Therefore, the curve represented by the total tourist arrivals extends over the TALC phases of Exploration, Involvement, Development, Consolidation, and Decline.

Regarding the urban context during this period, Ohrid's space rapidly changed during all stages. During the first stage Exploration (1956-1960), the overall economy collapsed, leaving Ohrid with the challenge of reconstructing basic facilities. The city lacked private initiatives for boosting tourism development, resulting in a total number of tourists that was low but constantly rising. Domestic tourists represented $91.1 \%$ of all tourist arrivals (an average for this stage) and were immeasurably dominant, accounting for ten times more visitors than foreigners. Tourism facilities were generally comprised of public boarding houses and vacation facilities for workers. There were only a dozen of publically owned hospitality enterprises with less than 1,000 beds in total. In 1960, the number of employees in the tourism and hospitality sector hardly reached 300. Ohrid was visited mainly by tourists attracted as individuals to independently organized visits. Local residents were not involved and the effects on the local economy were minimal.

During the Involvement stage (1961-1968), the number of tourists increased by $48 \%$ compared to the Exploration phase. Domestic tourists continued to be dominant, due primarily to the favorable discounts offered. The only decline was recorded in 1963, when a catastrophic earthquake destroyed the North Macedonian capital city of Skopje, which had provided a dominant share of Ohrid's domestic tourists. As per the urban transformation, some local churches and monasteries (like the Church of St. Sophia) began to be viewed as historical heritage sites. So, they began to host cultural events and concerts, making them not only sites of a spiritual character for local residents, but also tourist attractions [14]. Residents began to understand the positive effects on their livelihood of increased restaurant and accommodation demands. Almost all of the hotels were renovated, and the number of hospitality enterprises increased substantially to more than 40, with a total of more than 6,000 beds. As a result, the average length of stay increased to 5.7 days, or an entire day longer compared to the Exploration stage. 
In the Development stage (1969-1980) it was clear that tourism had become the priority sector of local development of Ohrid. The mean growth of tourism demand during this stage was $7.7 \%$, far exceeding the critical $2.5 \%$ threshold identified by [31] as an indicator of high development. The urban transformation was noted in the receptive motive, where the number of rooms and beds increased substantially. Thus, Ohrid could offer daily accommodations for more than 14,000 tourists [11]. The number of domestic tourists almost doubled and the number of international tourists tripled. Although total overnights increased by $66 \%$, the average length of stay decreased to 4.4 days, indicating that Ohrid needed to shift from a purely recreational approach (offering only sun, lake, and leisure) to promoting the cultural heritage of the city and the surrounding area.

During the Consolidation stage (1981-1985), the total number of tourists grew by $28 \%$ compared to the Development stage, indicating full development of the city's tourism functions. As noted by [21], the onset of this stage is often indicated by physical, psychosociological, and sociological criteria. Local authorities started to set strategic criteria for planning the tourism aspects of local development, which resulted in re-organization urban tourism in the city [22].

Unlike the case of North Macedonia where Stagnation stage exists according to the TALC model, [25], Ohrid directly entered the Decline stage (1986-1990). Ohrid recorded an $11 \%$ decline in the total number of tourists and a $27 \%$ decline in the total number of overnights. This was a result of a combination of several negative factors, like: lack of strategic vision for aircraft development in the country, instability in the surrounding region and armed conflicts, unfavorable political conditions, privatization of the stateowned companies, etc. The declining standard of living resulted in a rapid 39\% decrease in domestic tourist arrivals.

\section{Sub-Period II (1991-2001)}

The period between 1991 and 2001 can be considered a transitional stage for Ohrid's tourism and urban development, reflecting both the decline of the first cycle and, as the period following the independence of North Macedonia, the beginning of the second cycle in Sub-Period III. Many serious events with profoundly negative implications happened during this period, like: the collapse of former Yugoslavia which sparked numerous ethnic conflicts in North Macedonia's surrounding region (such as the war in Slovenia in 1991, the Croatian war of independence 1991-1995, the Bosnian war 1992-1995, and the war in Kosovo 1998-1999, including the NATO bombing), a refugee crisis, the establishment of a new monetary system and currency, the transformation from a planned to a freemarket economy, ethnic-conflicts, political crisis, and numerous issues of socioeconomic restructuring. So, the drop in tourism activity in Ohrid can be explained by both, internal and external factors, which caused further substantial change in the urban development.

\section{Sub-Period III (2002-2017)}

During this period, the cycle features only three stages: Exploration, Involvement, and Development. During the short Exploration stage (2002-2003), tourism in Ohrid was characterized by low publicity, inadequate tourism infrastructure and facilities, and unconvincing advertising.

In the Involvement stage (2004-2010), the local environment improved significantly in political and economic terms, which contributed to the expansion and enhancement of tourism facilities, areas and sites. As a result, the urban setting has dramatically changed and many new tourism attractions were opened. Local population came to understand the 
positive implications of tourism development. The more local residents gained from tourism, the more motivated they were to support tourism activities and protect the destination's natural and cultural environment [4], [19], [24].

The Development stage (2011-2017) was characterized by a progressive increase in the number of tourists, attracted by persuasive advertising and increased promotion. The urban space of Ohrid has completely changed. The local authorities played an important role in introducing a functional mix that led to the development of tourism, gastronomy (restaurants and pubs), and office space (i.e., commercial gentrification). A record high number of tourists visited Ohrid in 2017, representing an increase of $64.6 \%$ and an average annual growth rate of $4.6 \%$. The average number of tourists during this stage was 1.2 times greater than the average number of tourists recorded during previous two stages. Due to fact that the statistics on the apartments exchanged online do not provide the total number of transactions, the number of tourists could be even higher. Even more, with the online vacation rental platforms, the city suffered from increased tourist pressure. To this, one must add the unregistered tourists accommodated in large number of unregulated and officially not categorized accommodation capacities. Generally, tourists and visitors are interested in being accommodated in the core city, so the center during the high summer season is depopulated and the housing prices increase greatly. As in the case of Venice [34], Ohrid becomes the most expensive city in North Macedonia. Additionally, as of 2011, the air traffic noted a double-digit increase due to new regular and seasonal routes, thus leading to a rise in the number of foreign tourists. The low-budget airlines has helped attract young travelers wishing to discover Ohrid as a new destination. According to [28], such newcomers make up one-third of the tourism demand for Ohrid. In this way, as noted by [7], individual mass tourism has slowly shifted to organized mass tourism. Tourist activities have started to expand at a quicker pace, with the introduction of specific activities for tourists and visitors. The number of beds increased, reaching 14,173 beds in 2,743 private properties, in addition to 5,553 beds in 44 hotels [18].

As a total, Ohrid's life cycle curve was found to exhibit a double cycle sequence known as a cycle-recycle pattern [30]. As in the first sub-period, Ohrid has not reached the Consolidation stage and is therefore strongly believed to have stagnation in store. This could begin when the rate of tourists' visits begins to decrease despite growth in absolute figures. It is expected that Ohrid's tourism market will soon be saturated, and the introduction of new, innovative itineraries is therefore a priority for the promotion of diversified local tourist products.

\section{CONCLUSIONS AND RECOMMENDATIONS}

The paper focuses on Ohrid as a case study owing to both, the city's rapid growth in the realm of tourism and tourism's substantial importance to the local economy. Over the years, Ohrid has become a tourist destination under pressure with many tourism-related challenges, some of which have been resolved and others that continue to exist. The research analyzed various dimensions of the tourism context in order to understand them in the context of the city's urban development.

The study found Ohrid to be a city with an increasing tourism intensity and volume that raises questions of social and economic carrying capacity. The research revealed a double-cycle sequence, and the assessment suggests that Ohrid is in the Development stage of the TALC model. This means that Ohrid is attracting sufficient visitors and is still succeeding in maintaining control over undesirable social impacts, such as crime, 
overcrowding, rising prices, and local hostility, and has therefore reached a state of tourism maturity.

It is found that Ohrid faces major challenges as growing visitor arrivals impose increasing pressure on the city, both in physical and environmental terms (such as congestion, traffic, pressure on facilities and infrastructure) and in social and cultural terms (community tolerance, crime, quality of life). Its carrying capacity is exceeded, as rapid tourism growth in conjunction with inadequate infrastructure leads to overcrowding, particularly in the high season (the third-quarter of the year). Too much visitors aggravated by seasonality as in the case of Ohrid, is among the main causes for negative consequences of tourism known as visitor 'overkill' [32].

Yet, as many of the factors resulting in higher tourism vulnerability cannot be managed solely by tourism actors, there is a need for constant dialogue among all involved in the re-shaping of the city of Ohrid.

\section{REFERENCES}

[1] Ashworth, G. J., \& Tunbridge, J. E. The tourist-historic city: Retrospect and prospect of managing the heritage city. Amsterdam: Pergamon, 2000.

[2] Ballantyne, R., Hughes, K., Ding, P., \& Liu, D. Chinese and international visitor perceptions of interpretation at Beijing built heritage sites. Journal of Sustainable Tourism, 22(5), pp. 705725, 2014.

[3] Bellini, N., \& Pasquinelli, C. Tourism in the City: Towards an integrative agenda on urban tourism. Cham: Springer, 2016.

[4] Boley, B. B., McGehee, N. G., Perdue, R. R., \& Long, P. Empowerment and resident attitudes toward tourism: Strengthening the theoretical foundation through a Weberian lens. Annals of Tourism Research, 49, pp. 33-50, 2014.

[5] Butler, R. The concept of a tourist area cycle of evolution. Implications for management of resources. Canadian Geographer, 24(1), pp. 5-12, 1980.

[6] Canestrelli, E., \& Costa, P. Tourist carrying capacity: A fuzzy approach. Annals of Tourism Research, 18(2), pp. 295-311, 1991.

[7] Cohen, E. Towards a sociology of international tourism. Social Research, 39, pp. 164-182, 1972.

[8] Cohen-Hattab, K., \& Shoval, N. Tourism, religion and pilgrimage in Jerusalem. London: Routledge, 2015.

[9] Edwards, D., Griffin, T., \& Hayllar, B. Urban tourism research - Developing an agenda. Annals of Tourism Research, 35(4), pp. 1032-1052, 2008.

[10] Fainstein, S. S., \& Judd, R. D. Global forces, local strategies and urban tourism. In D. R. Judd \& S. S. Fainstein (Eds), The Tourist City (pp. 1-20). New Haven: Yale University Press, 1999.

[11] Filipovski, J. Ohridskoto stopanstvo. Združenie za nauka, kultura i umetnost Kliment Ohridski - Ohrid: Ohrid, 2005.

[12] Hoffman, L. M., Judd, D. R., \& Fainstein, S. S. (Eds.). Cities and visitors: Regulating people, markets, and city space. Oxford: Blackwell, 2003.

[13] Inskeep, E. Tourism Planning - An Integrated and Sustainable Development Approach. New York: Van Nostrand Reinhold, 1991.

[14] Institute for the Protection of the Cultural Monuments and the Museum of Ohrid. Decision on permanent return of the cultural landmarks to the Church, (in Macedonian), Executive Council 
of the Government of the Socialist Republic of Macedonia, No. 23-212/1 dated 24.01.1991, released in Official Gazette No. 6/21, 1991.

[15] Judd, D. R. The infrastructure of play: Building the tourist city. New York, NY: M. E. Sharpe, 2003.

[16] Law, C. M. Urban tourism: Attracting visitors to large cities. London: Mansell, 1993.

[17] Law, M. C. Tourism in Major Cities. London: International Thomson Business Press, 1996.

[18] LED - Local Economic Development Unit of the Municipality of Ohrid. Categorization of hotel establishments in Ohrid, Ohrid, 2018.

[19] Liu, Z. Sustainable tourism development: A critique. Journal of Sustainable Tourism, 11(6), pp. 459-475, 2003.

[20] Maitland, R., \& Newman, P. (Eds.). World tourism cities: Developing tourism off the beaten track. Abingdon: Routledge, 2009.

[21] Martin, B. S., \& Uysal, M. An examination of the relationship between carrying capacity and the tourism lifecycle: Management and policy implications. Journal of Environmental Management, 31(4), pp. 327-333, 1990.

[22] Mitrovic, N. Fotografijata kako istorisko svedostvo za gradot Ohrid vo periodot 1913-1991. Kosta Abras, Ohrid, 2015.

[23] Page, S. J. Urban tourism. London: Routledge, 1995.

[24] Perdue, R. R., Long, P.T., \& Allen, L. Resident support for tourism development. Annals of Tourism Research, 17(4), pp. 586-599, 1990.

[25] Petrevska, B. \& Collins-Kreiner, N. Double Life Cycle: Determining Tourism Development in Macedonia. Journal of Tourism and Cultural Change, 15(4), pp. 319-338, 2017.

[26] Petrevska, B. Tourism contribution to regional development: best practice in Macedonia. Journal of Community Positive Practices, 12(3/2012), pp. 425-440, 2012.

[27] Petrevska, B. Effects of tourism seasonality at local level. Scientific Annals of the “Alexandru Ioan Cuza" University of Iasy, Economic Sciences Series, 62(2), pp. 241-250, 2015.

[28] Petrevska, B. Tourists' perception: the case of Ohrid, Macedonia. Acta Geobalcanica, 5(2), pp. 75-84, 2019.

[29] Petrovski, Z. \& Talevski, S. The Mirror of the Macedonian Spirit. Napredok, 2004.

[30] Rink, D. R., \& Swan, J. E. Product life cycle research: A literature review. Journal of Business Research, 7(3), pp. 219-242, 1979.

[31] Romão, J., Guerreiro, J. \& Rodrigues, P. Regional tourism development: culture, nature, life cycle and attractiveness. Current Issues in Tourism, 16(6), pp. 517-534, 2013.

[32] Rosenow, J. E., \& Pulsipher, G. L. Tourism the Good, the Bad, and the Ugly. Media Productions \& Marketing: Lincoln, NE, USA, 1979.

[33] Russo, A. P. The 'Vicious Circle' of tourism development in historic cities. Annals of Tourism Research, 29(1), pp. 165-182, 2001.

[34] Seraphin, H., Sheeran, P. \& Pilato, M. Over-tourism and the fall of Venice as a destination. Journal of Destination Marketing \& Management, 9, pp. 374-376, 2018.

[35] Shoval, N. Tourism and Urban Planning in European Cities. UK: Routledge, 2018.

[36] Spirou, C. Urban tourism and urban change: Cities in a global economy. New York: Routledge, 2011.

[37] UNESCO. Convention concerning the protection of the World cultural and natural heritage, (Doc WHC/19/43.COM/18). Paris: UNESCO World Heritage Committee, 2019. 
[38] Upchurch, R.S., \& Teivane, U. Resident perceptions of tourism development in Riga, Latvia. Tourism Management, 21, pp. 499-507, 2000.

[39] van der Borg, J., Costa, P., \& Gotti, G. Tourism in European heritage cities. Annals of Tourism Research, 23(2), pp. 306-321, 1996.

[40] Vankovska, B. \& Wiberg, H. Between Past and Future: Civil-Military Relations in PostCommunist Balkan states, Tom 17, I. B. Taurus, 2003.

[41] Weber, F., Stettler, J., Priskin, J., Rosenberg-Taufer, B., Ponnapureddy, S., Fux, S., Camp, M-A., \& Barth, M. Tourism destinations, under pressure: Challenges and innovation solutions. Lucerne University of Applied Sciences and Arts, 2017. 